Article

\title{
A Water-Stable 2-Fold Interpenetrating cds Net as a Bifunctional Fluorescence-Responsive Sensor for Selective Detection of $\mathrm{Cr}$ (III) and $\mathrm{Cr}(\mathrm{VI})$ Ions
}

\author{
Meng-Jung Tsai, Kuo-Shun Liao and Jing-Yun Wu *D \\ Department of Applied Chemistry, National Chi Nan University, Nantou 545, Taiwan; \\ s97324905@mail1.ncnu.edu.tw (M.-J.T.); aasd6307@gmail.com (K.-S.L.) \\ * Correspondence: jyunwu@ncnu.edu.tw
}

check for

updates

Citation: Tsai, M.-J.; Liao, K.-S.; Wu, J.-Y. A Water-Stable 2-Fold Interpenetrating cds Net as a Bifunctional Fluorescence-Responsive Sensor for Selective Detection of Cr(III) and $\mathrm{Cr}$ (VI) Ions. Nanomaterials 2022, 12, 158. https://doi.org/10.3390/ nano12010158

Academic Editor: Antonios Kelarakis

Received: 18 November 2021

Accepted: 1 January 2022

Published: 3 January 2022

Publisher's Note: MDPI stays neutral with regard to jurisdictional claims in published maps and institutional affiliations.

Copyright: (C) 2022 by the authors. Licensee MDPI, Basel, Switzerland. This article is an open access article distributed under the terms and conditions of the Creative Commons Attribution (CC BY) license (https:// creativecommons.org/licenses/by/ $4.0 /)$.

\begin{abstract}
Reactions of $\mathrm{ZnSO}_{4} \cdot 7 \mathrm{H}_{2} \mathrm{O}, \mathrm{N}$-(pyridin-3-ylmethyl)-4-(pyridin-4-yl)-1,8-naphthalimide (NI-mbpy-34), and 5-bromobenzene-1,3-dicarboxylic acid (Br-1,3- $\mathrm{H}_{2}$ bdc) afforded a luminescent coordination polymer, $[\mathrm{Zn}(\mathrm{Br}-1,3-\mathrm{bdc})(\mathrm{NI}-\mathrm{mbpy}-34)]_{n}$ (1), under hydro(solvo)thermal conditions. Single-crystal X-ray structure analysis revealed that $\mathbf{1}$ features a three-dimensional (3-D) 2-fold interpenetrating cds (or $\mathrm{CdSO}_{4}$ ) net topology with the point symbol of $\left(6^{5} \cdot 8\right)$, where the $\mathrm{Zn}$ (II) centers are considered as 4-connected square-planar nodes. X-ray powder diffraction (XRPD) patterns and thermogravimetric (TG) analysis confirmed that $\mathbf{1}$ shows high chemical and thermal stabilities. Notably, 1 displayed solvent dependent photoluminescence properties; the fluorescence intensity and emission maximum of $\mathbf{1}$ in different solvent suspensions varied when a solvent was changed. Furthermore, the $\mathrm{H}_{2} \mathrm{O}$ suspension of $\mathbf{1}$ exhibited blue fluorescence emission and thus can be treated as a selective and sensitive fluorescent probe for turn-on detection of $\mathrm{Cr}^{3+}$ cations through absorbance caused enhancement (ACE) mechanism and turn-off detection of $\mathrm{Cr}_{2} \mathrm{O}_{7}{ }^{2-} / \mathrm{CrO}_{4}{ }^{2-}$ anions through collaboration of the absorption competition and energy transfer process, with limit of detection (LOD) as low as $\mu \mathrm{M}$ scale.
\end{abstract}

Keywords: chromium; coordination polymer; fluorescence sensor; interpenetrating

\section{Introduction}

The monitoring and detection of chemical pollutants and/or controlled chemicals in complicated samples are very important tasks in managing the environment, water resources, and the food industry. Among various conventional instrumental techniques, fluorescence sensing responding to fluorescence turn on, turn off, or ratiometric signal, has attracted immense attention in recent years because of its particular aspects such as economics, user-friendliness, short response time, visualization, monitoring in real-time, excellent sensitivity, and high selectivity [1-4]. Various advanced fluorophore materials, including organic dyes [5,6], porous organic polymers [7], quantum dots (QDs) [8,9], carbon dots (CDs) [1,2], nanoparticles (NPs) [3,10], lanthanide organic/inorganic hybrid materials (LHMs) [11], and metal-organic frameworks/coordination polymers (MOFs/CPs) [12-14] have emerged.

Chromium existing as $\mathrm{Cr}(\mathrm{III})$ and $\mathrm{Cr}(\mathrm{VI})$ oxidation states in the aquatic environments can directly contaminate the soil and aquatic systems. As an essential trace biological element in humans, $\mathrm{Cr}$ (III) is considered to be harmless and safe. However, excessive $\mathrm{Cr}(\mathrm{III})$ may combine with DNA to cause mutations and malignant cells [10,15-17]. Cr(VI) shows high carcinogenicity and mutagenicity and can cause allergic reactions, hereditary genetic defects and various types of cancers that adversely affect human health [17-19]. The World Health Organization (WHO) has claimed a permissible limit of $50 \mu \mathrm{g} / \mathrm{L}$ for $\mathrm{Cr}(\mathrm{VI})$ in drinking water [20]. Lately, MOF/CP-based, fluorescence-sensory materials have been actively pursued as excellent platforms for the flourishing utilization in detection of $\mathrm{Cr}$ (III) 
and $\mathrm{Cr}(\mathrm{VI})$ ions though fluorescence quenching (turn off) effect [15,21-45]. However, there are still rare examples to achieve the detection of $\mathrm{Cr}$ (III) via the fluorescence enhancement (turn on) response [15,43-48] and fluorescence shift (ratiometric) effect [41-43].

As part of our ongoing work in fluorescence detection of hazardous chemical contaminants [39-44,49-52], we acquired, herein, a Zn(II)-based luminescent coordination polymer, namely $[\mathrm{Zn}(\mathrm{Br}-1,3-b d c)(\mathrm{NI}-\mathrm{mbpy}-34)]_{n}$ (1, Br-1,3-bdc = 5-bromobenzene-1,3dicarboxylate; NI-mbpy-34 = N-(pyridin-3-ylmethyl)-4-(pyridin-4-yl)-1,8-naphthalimide), featuring a three-dimensional (3-D) 2-fold interpenetrating cds net. Of note, coordination polymer 1 exhibited fluorescence emissions in solid-state and solvent suspensions, being a bifunctional fluorescence sensor for sensitively and selectively detecting chromium(III) cations and chromium(VI) oxyanions.

\section{Experimental Section}

\subsection{Materials and Methods}

All of the chemicals and solvents were acquired from market sources and used without further processing. Ligand NI-mbpy-34 was synthesized according to the previously reported literature [44]. The thermal analysis was conducted by a Thermo Cahn VersaTherm HS TG analyzer (Thermo, Newington, NH, USA) from 25 to $900{ }^{\circ} \mathrm{C}$ at a heating rate of $5^{\circ} \mathrm{C} / \mathrm{min}$ under a flow of nitrogen. The X-ray powder diffraction (XRPD) patterns were measured in the $2 \theta$ range of $5-50^{\circ}$ by a Shimadzu XRD-7000 diffractometer (Shimadzu, Kyoto, Japan) using $\mathrm{Cu} \mathrm{K} \alpha$ radiation $(\lambda=1.5406 \AA)$ operating at $30 \mathrm{kV}$ and $30 \mathrm{~mA}$. Infrared (IR) spectroscopy was tested in a Perkin-Elmer Frontier Fourier transform infrared spectrometer (Perkin-Elmer, Taipei, Taiwan), and the region $4000-500 \mathrm{~cm}^{-1}$ was recorded with attenuated total reflection (ATR) technique. UV-Vis absorption spectra were obtained on a JASCO V-750 UV/VIS spectrophotometer (JASCO, Tokyo, Japan) at room temperature. The solid-state and solution fluorescence spectra were measured on a Hitachi F7000 fluorescence spectrophotometer (Hitachi, Tokyo, Japan) at room temperature, with the excitation and emission slits of $5 \mathrm{~nm} \times 5 \mathrm{~nm}$ and a scan rate of $1200 \mathrm{~nm} / \mathrm{min}$. A $150 \mathrm{~W}$ xenon arc lamp was used as an exciting light source. Elemental analyses of $C, H$, and $\mathrm{N}$ were performed on a Vario EL III elemental analyzer (Elementar, Langenselbold, Germany). X-ray photoelectron spectroscopy (XPS) was measured by an ULVAC-PHI PHI 5000 VersaProbe/Scanning ESCA Microprobe instrument (ULVACPHI Inc., Kanagawa, Japan).

\subsection{Synthesis of $[\mathrm{Zn}(\mathrm{Br}-1,3-b d c)(N I-m b p y-34)]_{n}(\mathbf{1})$}

NI-mbpy-34 (9.1 mg, $0.025 \mathrm{mmol})$ was dissolved in $2 \mathrm{~mL}$ of $N, N^{\prime}$-dimethylformamide (DMF); $\mathrm{ZnSO}_{4} \cdot 7 \mathrm{H}_{2} \mathrm{O}(14.3 \mathrm{mg}, 0.050 \mathrm{mmol})$ was dissolved in $2 \mathrm{~mL}$ of $\mathrm{H}_{2} \mathrm{O}$; $\mathrm{Br}-1,3-\mathrm{H}_{2}$ bdc $(12.3 \mathrm{mg}, 0.050 \mathrm{mmol})$ was dissolved in $1 \mathrm{~mL}$ of DMF. The above-mentioned solutions were sequentially added to a $23 \mathrm{~mL}$ Teflon-lined stainless steel reactor placed in an autoclave. This was sealed and then heated to $80^{\circ} \mathrm{C}$ for $6 \mathrm{~h}$ and kept at $80{ }^{\circ} \mathrm{C}$ for $48 \mathrm{~h}$. After slowly cooling to $30^{\circ} \mathrm{C}$ for $36 \mathrm{~h}$, the mixture was washed with distilled water and ethanol, and yellowish crystals were filtered off and dried. The yield based on NI-mbpy-34 was about $60 \%$. IR (ATR, $\mathrm{cm}^{-1}$ ): 3071, 1617, 1322, 1462, 990, 884, 723. Anal. Calcd for $\mathrm{C}_{31} \mathrm{H}_{18} \mathrm{BrN}_{3} \mathrm{O}_{6} \mathrm{Zn}$ : C, 55.21; H, 2.67; N, 6.23\%. Found: C, 54.90; H, 2.65; N, 6.20\%.

\subsection{Single-Crystal X-ray Structure Determinations}

The single-crystal data taken at $150(2) \mathrm{K}$ for $\mathbf{1}$ were collected on a Bruker D8 Venture diffractometer with a graphite monochromated Mo $\mathrm{K} \alpha$ radiation $(\lambda=0.71073 \AA)$ and a PHOTO100 CMOS detector. The structures were solved by direct methods using SHELXTL [53] and refined on $F^{2}$ by the full-matrix least-squares using the SHELXL2014/7 [54] and WINGX [55]. Non-hydrogen atoms were confirmed by successive difference Fourier syntheses and were refined with anisotropic displacement parameters. The hydrogen atoms were produced theoretically on their calculated positions and refined with isotropic displacement parameters set to $1.2 U_{e q}$ of the attached atom. The single-crystal data and refinement parameters of $\mathbf{1}$ are summarized in Table 1. CCDC 
1991626 (1) contains the supplementary crystallographic data for this paper. These data can be obtained free of charge from the Cambridge Crystallographic Data Centre via www.ccdc.cam.ac.uk/data_request/cif (23 December 2022).

Table 1. Crystallographic data for 1.

\begin{tabular}{|c|c|}
\hline & 1 \\
\hline Empirical formula & $\mathrm{C}_{31} \mathrm{H}_{18} \mathrm{BrN}_{3} \mathrm{O}_{6} \mathrm{Zn}$ \\
\hline$M_{\mathrm{W}}$ & 673.76 \\
\hline Crystal system & Monoclinic \\
\hline Space group & $C 2 / c$ \\
\hline$a, \AA$ & $14.254(2)$ \\
\hline$b, \AA$ & $12.566(2)$ \\
\hline$c, \AA$ & $29.985(5)$ \\
\hline$\beta, \circ$ & $102.648(8)$ \\
\hline$V, \AA^{3}$ & $5240.2(15)$ \\
\hline Z & 8 \\
\hline$T, \mathrm{~K}$ & $150(2)$ \\
\hline$\lambda, \AA$ & 0.71073 \\
\hline$D_{\text {calc }}, \mathrm{g} \mathrm{cm}^{-3}$ & 1.708 \\
\hline$F_{000}$ & 2704 \\
\hline$\mu, \mathrm{mm}^{-1}$ & 2.516 \\
\hline Reflns collected & 43704 \\
\hline Unique reflns $\left(R_{\text {int }}\right)$ & $5360(0.0751)$ \\
\hline Obsd reflns $(I>2 \sigma(I))$ & 4534 \\
\hline Params & 379 \\
\hline$R_{1}{ }^{a}, w R_{2}{ }^{b}(I>2 \sigma(I))$ & $0.0633,0.1296$ \\
\hline$R_{1}{ }^{a}, w R_{2}^{b}$ (all data) & $0.0778,0.1353$ \\
\hline GOF on $F^{2}$ & 1.114 \\
\hline$\Delta \rho_{\max }, \Delta \rho_{\min }, \mathrm{e} \AA^{-3}$ & $1.312,-0.916$ \\
\hline
\end{tabular}

${ }^{a} R_{1}=\sum|| F_{o}|-| F_{c}|| / \sum\left|F_{o}\right| \cdot{ }^{b} w R_{2}=\left\{\sum\left[w\left(F_{o}{ }^{2}-F_{c}{ }^{2}\right)^{2}\right] / \sum\left[w\left(F_{o}{ }^{2}\right)^{2}\right]\right\}^{1 / 2}$.

\subsection{Fluorescence Measurements}

Finely ground powders of $\mathbf{1}(1 \mathrm{mg})$ were suspended in various solvents $(3 \mathrm{~mL})$ including dichloromethane $\left(\mathrm{CH}_{2} \mathrm{Cl}_{2}\right), N, N^{\prime}$-dimethylacetamide (DMAc), $N, N^{\prime}$-dimethylformamide (DMF), $\mathrm{H}_{2} \mathrm{O}$, methanol $\left(\mathrm{CH}_{3} \mathrm{OH}\right)$, and toluene. The prepared suspensions were ultrasonicated via pulsed ultrasound for $10 \mathrm{~min}$ and then agitated for further $30 \mathrm{~min}$ to yield more stable suspensions.

The $\mathrm{H}_{2} \mathrm{O}$ suspensions of $\mathbf{1}$ were utilized to conduct fluorescence sensing experiments. Aqueous solutions of metal ions, including $\mathrm{AgNO}_{3}, \mathrm{Al}\left(\mathrm{NO}_{3}\right)_{3}, \mathrm{Mg}\left(\mathrm{NO}_{3}\right)_{2}, \mathrm{Ca}\left(\mathrm{NO}_{3}\right)_{2}$, $\mathrm{Co}\left(\mathrm{NO}_{3}\right)_{2}, \mathrm{Cr}\left(\mathrm{NO}_{3}\right)_{3}, \mathrm{Cu}\left(\mathrm{NO}_{3}\right)_{2}, \mathrm{Fe}\left(\mathrm{NO}_{3}\right)_{3}, \mathrm{NaNO}_{3}, \mathrm{KNO}_{3}, \mathrm{Mn}\left(\mathrm{NO}_{3}\right)_{2}, \mathrm{Ni}\left(\mathrm{NO}_{3}\right)_{2}$, and $\mathrm{Pb}\left(\mathrm{NO}_{3}\right)_{2}$, and anions, including $\mathrm{NaF}, \mathrm{KCl}, \mathrm{KBr}, \mathrm{KI}, \mathrm{KClO}_{4}, \mathrm{~K}_{2} \mathrm{CO}_{3}, \mathrm{~K}_{2} \mathrm{Cr}_{2} \mathrm{O}_{7}, \mathrm{~K}_{2} \mathrm{CrO}_{4}, \mathrm{KNO}_{3}$, and $\mathrm{K}_{3} \mathrm{PO}_{4}$ were prepared with concentration of $0.10 \mathrm{M}$ for fluorescence sensing studies.

Qualitative studies were carried out by adding $0.10 \mathrm{M}$ analyte $(30 \mu \mathrm{L})$ into the wellprepared $\mathrm{H}_{2} \mathrm{O}$ suspensions of $\mathbf{1}$; then, the fluorescence spectra were recorded after waiting for $3 \mathrm{~min}$. Anti-interference studies were conducted on a series of competition experiments with addition of the solution of different perturbed analytes $(0.10 \mathrm{M}, 30 \mu \mathrm{L})$ followed by the targeted analyte $(0.10 \mathrm{M}, 30 \mu \mathrm{L})$ into the $\mathrm{H}_{2} \mathrm{O}$ suspensions. In each step, the fluorescence spectra were recorded.

The fluorescence quantitative titration experiments were performed with the gradual addition of analytes in aqueous solutions $(0.10 \mathrm{M})$, and then the fluorescence spectra were monitored. The Stern-Volmer equation: $I_{0} / I=1+K_{\mathrm{sv}}[\mathrm{Q}]$, where $I_{0}$ and $I$ denote the fluorescence intensities before and after the addition of analytes, respectively, $K_{\mathrm{sv}}$ is the Stern-Volmer quenching constant $\left(\mathrm{M}^{-1}\right)$, and $[\mathrm{Q}]$ is the concentration of analyte $(\mathrm{mM})$, was applied to quantitatively analyze the fluorescence quenching effect.

Limit of detection (LOD) determinations were performed at low concentrations of analyte. Prior to the fluorescence titration, five blank measurements of fluorescence for the 
$\mathrm{H}_{2} \mathrm{O}$ suspensions of 1 were carried out for determining the standard deviation $(\sigma)$. LODs were calculated using the equation: $\mathrm{LOD}=3 \sigma / k$, where $k$ represents the absolute value of the slope of the calibration curve.

\section{Results and Discussion}

\subsection{Crystal Structure of $[\mathrm{Zn}(\mathrm{Br}-1,3-b d c)(\mathrm{NI}-\mathrm{mbpy}-34)]_{n}$ (1)}

Single-crystal X-ray structure analysis reveals that the crystal structure of $\mathbf{1}$ belongs to the monoclinic space group C2/c. There is one cationic $\mathrm{Zn}$ (II) center, one fully-deprotonated $\mathrm{Br}-1,3-\mathrm{bdc}^{2-}$ anion, and one neutral NI-mbpy-34 ligand in the asymmetric unit. The $\mathrm{Zn}$ (II) center is surrounded by two oxygen atoms of two carboxylate groups from two distinct $\mathrm{Br}-$ 1,3-bdc ${ }^{2-}$ ligands and two nitrogen atoms of one 3-pyridyl (imide end) and one 4-pyridyl (naphthalene end) groups from two distinct NI-mbpy-34 ligands to adopt a $\left\{\mathrm{ZnO}_{2} \mathrm{~N}_{2}\right\}$ tetrahedral geometry (Figure $1 \mathrm{a}$ ). The anionic $\mathrm{Br}-1,3-\mathrm{bdc}^{2-}$ ligand has a $\mu_{2}-\mathrm{Br}-1,3-\mathrm{bdc}-$ $\mathrm{\kappa O}: \mathrm{kO}$ mode to bridge two $\mathrm{Zn}(\mathrm{II})$ centers; each of the two carboxylate groups is in a monodentate- $\mathrm{KO}$ coordination mode (Figure $1 \mathrm{~b}$ ). The $\mathrm{Zn}(\mathrm{II})$ centers are connected by the anionic Br-1,3-bdc ${ }^{2-}$ and the neutral NI-mbpy-34 ligands to form a three-dimensional (3-D) porous framework (Figure 1c). If the $\mathrm{Zn}$ (II) centers are considered as 4-connected square-planar nodes and both the Br-1,3-bdc ${ }^{2-}$ and NI-mbpy-34 ligands are considered as linear linkers (Figure 1a), the 3-D framework of 1 can be simplified as a 4 -connected cds (or $\mathrm{CdSO}_{4}$ ) net topology with the point symbol of $\left(6^{5} \cdot 8\right)$ (Figure $1 \mathrm{~d}$ ). The potential voids of the single cds network are occupied by the other independent identical framework via interpenetration in opposite orientation to generate a 2-fold interpenetrating net (Figure 1e), leaving insufficient solvent accessible voids. Notably, two neighboring naphthalimide skeletons in the two independent equivalent cds frameworks are nearly parallel in a headto-tail manner and the distance between them is about $3.50 \AA$ (Figure S1), suggesting significant $\pi-\pi$ interactions.

a

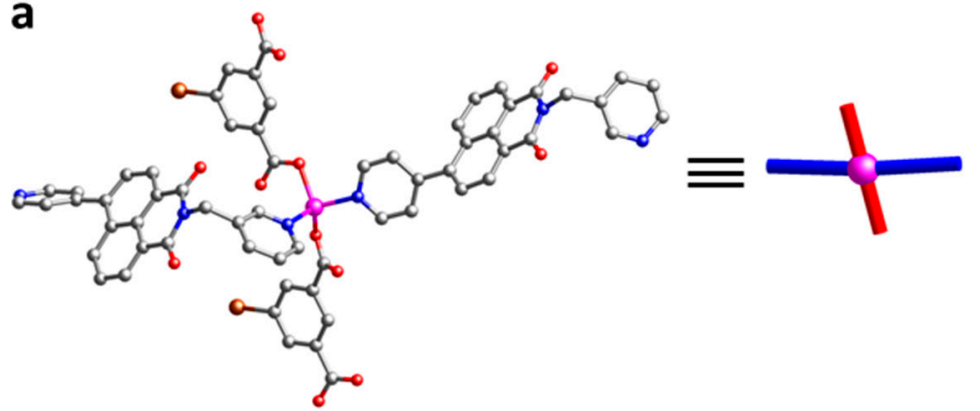

b

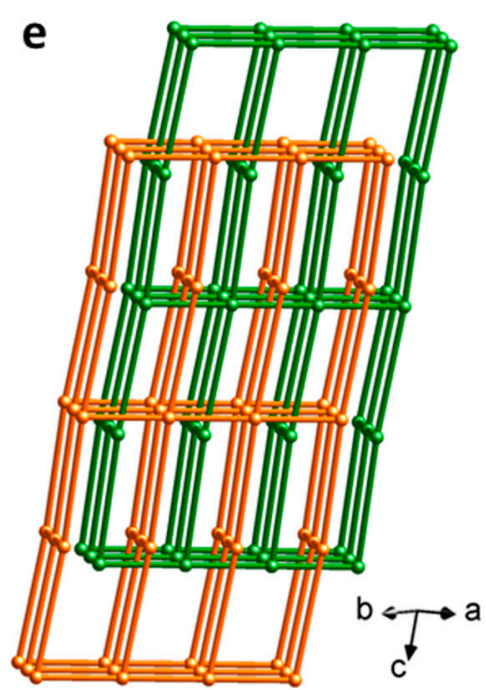

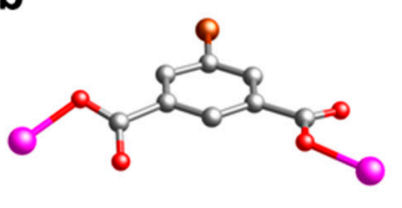

C

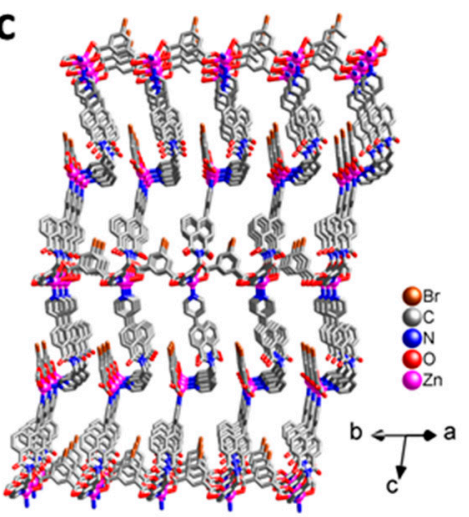

d

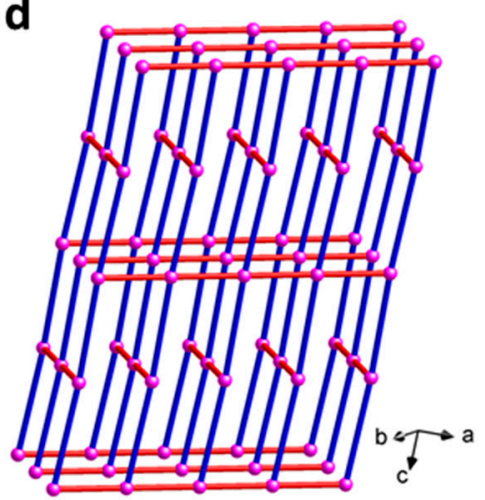

Figure 1. Crystal structure of 1: (a) the coordination environment around the $\mathrm{Zn}$ (II) center and schematic representation of the 4-connected node; (b) the coordination mode of $\mathrm{Br}-1,3-\mathrm{bdc}^{2-}$ dianion; (c) a single 3-D framework; (d) schematic representation of the 4-connected cds network with the point symbol of $\left(6^{5} \cdot 8\right)$; (e) 2-fold interpenetrating cds networks. 


\subsection{X-ray Powder Diffraction (XRPD) Patterns and Chemical Stability}

$\mathrm{X}$-ray powder diffraction (XRPD) patterns of as-synthesized $\mathbf{1}$ are in agreement with the simulated patterns calculated from single-crystal X-ray diffraction data (Figure 2), confirming the phase purity of bulky samples. Further, the chemical stability of $\mathbf{1}$ in different solvents was checked. After immersing in dichloromethane $\left(\mathrm{CH}_{2} \mathrm{Cl}_{2}\right), N, N^{\prime}-$ dimethylacetamide (DMAc), $N, N^{\prime}$-dimethylformamide (DMF), $\mathrm{H}_{2} \mathrm{O}$, methanol $\left(\mathrm{CH}_{3} \mathrm{OH}\right)$, and toluene for $24 \mathrm{~h}$, the XRPD patterns of the solvent-treated samples showed that the characteristic peaks match well with those of the XRPD pattern of as-synthesized $\mathbf{1}$ and that simulated from the single crystal data, although the peak intensities are somewhat different (Figure 2). This demonstrates that the original framework of 1 can retain a high crystallinity after immersion in solvents, confirming its high stability.

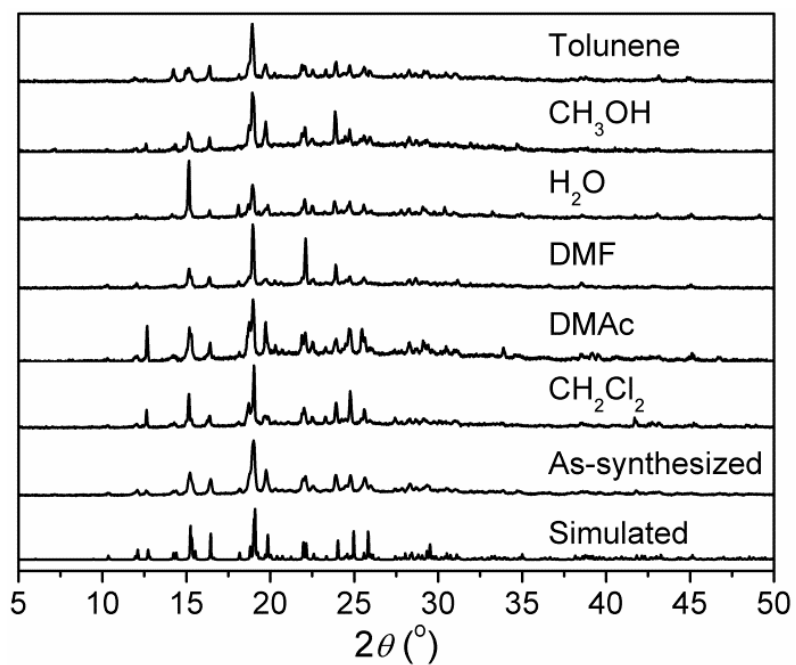

Figure 2. Simulated XRPD pattern of $\mathbf{1}$ and XRPD patterns of as-synthesized $\mathbf{1}$ and $\mathbf{1}$ immersed in different solvents for $24 \mathrm{~h}$.

\subsection{Thermal Properties}

The thermal properties of $\mathbf{1}$ were evaluated from the thermogravimetric (TG) analysis. As a representative, the TG analysis plot of 1 shows no weight loss before $378{ }^{\circ} \mathrm{C}$ (Figure S2), indicating high thermal stability. Then a two-step decomposition of the framework occurred, which was ended upon heating to ca. $640^{\circ} \mathrm{C}$. During the decomposition, bromide might react with divalent zinc to generate $\mathrm{ZnBr}_{2}$ (b.p. $=697^{\circ} \mathrm{C}$ ), which escaped at higher temperature. The remaining residue of $6.2 \%$ was reasonably assigned to the $\mathrm{ZnO}$ component (calcd 6.0\%).

\subsection{Photoluminescence Properties}

Previous research has shown that NI-mbpy-34 is highly emissive and can be a luminescence source for coordination polymers due to its highly conjugated $\pi$-electron system [44]. In solid-state, NI-mbpy-34 showed emission band(s) in the region of 400-600 nm with maximum at $462 \mathrm{~nm}$ upon excitation at $\lambda_{\mathrm{ex}}=370 \mathrm{~nm}$, while $\mathrm{Br}-1,3-\mathrm{H}_{2} \mathrm{bdc}$ displayed only an extremely weak emission band upon excitation at $\lambda_{\mathrm{ex}}=360 \mathrm{~nm}$ (Figure S3). When excited at $\lambda_{\mathrm{ex}}=306 \mathrm{~nm}, \mathbf{1}$ exhibited solid-state fluorescence with two emission peaks centered at $444 \mathrm{~nm}$ and $504 \mathrm{~nm}$. From the band position and shape, the emissions were tentatively attributed to the ligand-centered emission of NI-mbpy-34 perturbed by metal coordination.

Subsequently, the fluorescence properties of $\mathbf{1}$ in different solvent suspensions, such as $\mathrm{CH}_{2} \mathrm{Cl}_{2}$, DMAc, DMF, $\mathrm{H}_{2} \mathrm{O}, \mathrm{CH}_{3} \mathrm{OH}$, and toluene were also investigated (Figure 3). We observed that the fluorescence intensity and emission maximum of $\mathbf{1}$ in different solvent suspensions varied as the solvent was changed, implying solvent-dependent photoluminescence properties. Upon excitation, 1 emitted strong fluorescence emissions in $\mathrm{CH}_{3} \mathrm{OH}$ and DMF suspensions, moderate emissions in $\mathrm{H}_{2} \mathrm{O}$ and DMAc suspensions, and weak 
emissions in $\mathrm{CH}_{2} \mathrm{Cl}_{2}$ and toluene suspensions. In addition, the emission maxima of these suspensions varied from $384 \mathrm{~nm}$ to $432 \mathrm{~nm}$, showing remarkable blue shift compared to the solid-state fluorescence. The phenomena can most likely be attributed to the different collision interactions rather than crystal structure change $[56,57]$, since that $\mathbf{1}$ is highly stable in all chosen solvents. Additionally, it is noted that the fluorescence emission intensities are nearly directly proportional to the concentrations of $\mathbf{1}$ in $\mathrm{H}_{2} \mathrm{O}$ suspensions (Figure S4).

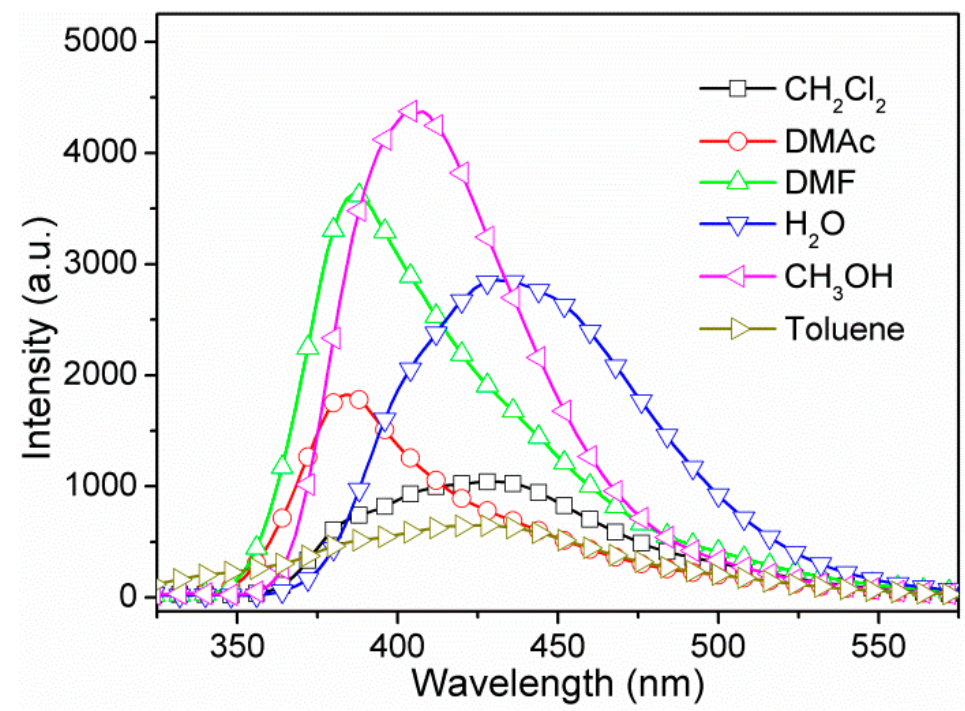

Figure 3. Fluorescence emission spectra of $\mathbf{1}$ in suspension-phase of different solvents.

\subsection{Fluorescence Sensing of Metal Ions}

The fluorescence sensing properties of 1 toward metal ions have been explored, and the fluorescence sensing measurements were carried out in water. Aqueous solutions of nitrate salt of thirteen different metal ions, including $\mathrm{Ag}^{+}, \mathrm{Al}^{3+}, \mathrm{Mg}^{2+}, \mathrm{Ca}^{2+}, \mathrm{Co}^{2+}, \mathrm{Cr}^{3+}, \mathrm{Cu}^{2+}, \mathrm{Fe}^{3+}$, $\mathrm{Na}^{+}, \mathrm{K}^{+}, \mathrm{Mn}^{2+}, \mathrm{Ni}^{2+}$, and $\mathrm{Pb}^{2+}$, were separately added into the $\mathrm{H}_{2} \mathrm{O}$ suspensions of $\mathbf{1}$ in a quartz cuvette with the concentration at $1.0 \mathrm{mM}$. The photoluminescence measurements were obtained at an excitation wavelength of $306 \mathrm{~nm}$ before and after addition of metal ions under the same experimental conditions (Figure 4a). Upon addition of the different metal ions, the mono- and divalent metal ions exerted a relatively weak effect (intensity change $\leq 10 \%$ ) on the emission of 1 , and the $\mathrm{Fe}^{3+}$ ion addition led to a weak enhancement effect with ca. 20-nm blue shift. Interestingly, the trivalent metal ions of $\mathrm{Cr}^{3+}$ and $\mathrm{Al}^{3+}$ resulted in a remarkable fluorescence enhancement by 8.7 and 3.3 times, respectively, along with ca. $20-\mathrm{nm}$ blue shift. The results demonstrate that $\mathbf{1}$ may be an excellent fluorescence sensor for $\mathrm{Cr}^{3+}$ detection with efficient selectivity. To confirm our assumption, interference experiments were carried out to examine the ability of 1 to selectively detect $\mathrm{Cr}^{3+}$ ions in the co-existence of interfering metal ions with equal concentrations of $1.0 \mathrm{mM}$. Experimental results clearly indicated that in sensing $\mathrm{Cr}^{3+}$ by $\mathbf{1}, \mathrm{Al}^{3+}$ displayed strong competitive effect while other selected perturbed metal ions showed insignificant interference (Figure 5), suggesting that $\mathbf{1}$ has good selectivity along with anti-interference ability for $\mathrm{Cr}^{3+}$ sensing in water. Briefly stated, $\mathbf{1}$ is highly selective for $\mathrm{Cr}^{3+}$ detection over other perturbed metal ions with the exception of $\mathrm{Al}^{3+}$. Further studies on $\mathrm{Cr}^{3+}$ detection by varying the concentrations of 1 in $\mathrm{H}_{2} \mathrm{O}$ suspensions showed almost unchanged fluorescence enhancement ratios (Figure S5), suggesting specific $\mathrm{Cr}^{3+}$ sensing performances in water.

To further investigate the sensitivity of $\mathbf{1}$ toward $\mathrm{Cr}^{3+}$ ions, the fluorescence titration experiments were executed. As expected, gradually increasing fluorescence emission intensities were observed at around $420 \mathrm{~nm}$ with increasing concentrations of $\mathrm{Cr}^{3+}$ ions. As shown in Figure $6 \mathrm{~b}$, there exists a nonlinear relationship between the fluorescence intensity and the $\mathrm{Cr}^{3+}$ ion concentration, with the formula of $I=-2823.98 \times \exp \left(-\left[\mathrm{Cr}^{3+}\right] / 0.83\right)+2906.06$ $\left(R^{2}=0.9929\right)$, suggesting a saturation behavior at high concentrations. On the basis 
of quantitative titrations (Figure S6), the LOD for $\mathrm{Cr}^{3+}$ was determined to be $3.13 \mu \mathrm{M}$ (corresponding to $162.9 \mathrm{ppb}$ ). This proves that 1 can effectively detect $\mathrm{Cr}^{3+}$ ions with remarkable sensitivity.

a

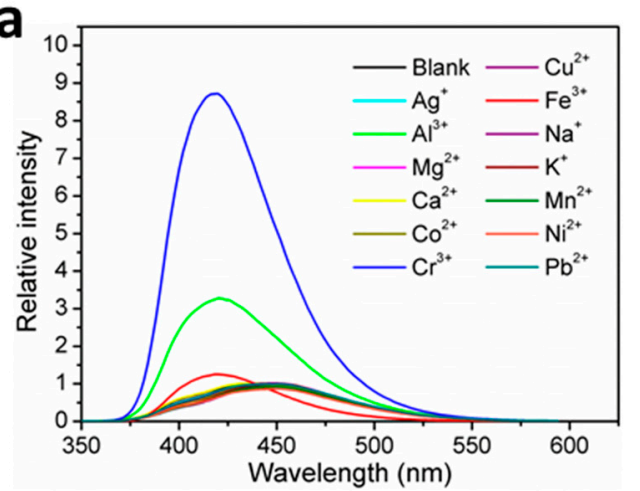

b

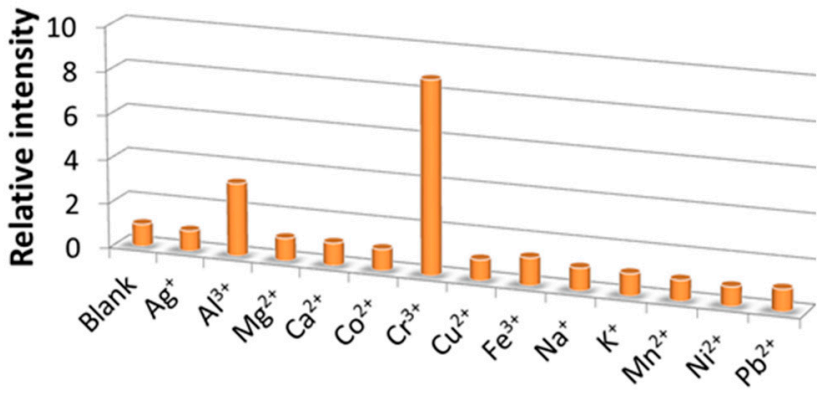

Figure 4. (a) Fluorescence emission spectra, and; (b) fluorescence relative ratio responses of $\mathbf{1}$ in $\mathrm{H}_{2} \mathrm{O}$ suspensions containing various metal ions at $1.0 \mathrm{mM}$.

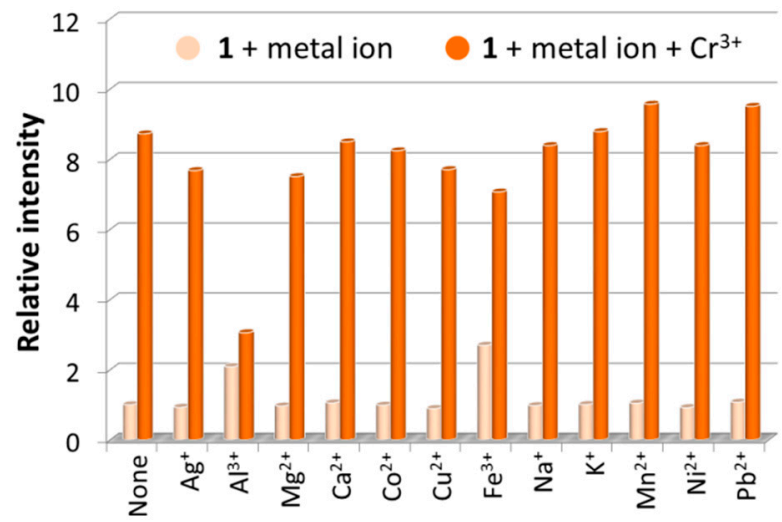

Figure 5. Fluorescence relative ratio responses of $\mathbf{1}$ in $\mathrm{H}_{2} \mathrm{O}$ suspensions containing various metal ions before and after addition of $\mathrm{Cr}^{3+}$ ions with equal concentrations at $1.0 \mathrm{mM}$.

The possible fluorescence sensing mechanism toward $\mathrm{Cr}^{3+}$ was investigated. The XRPD patterns of 1 recovered from $\mathrm{Cr}^{3+}$ aqueous solutions showed high consistency with the XRPD patterns of as-synthesized 1 in peak positions (Figure S7), which suggested that the framework of 1 keeps its integrity after $\mathrm{Cr}^{3+}$ detection. Thus, the turn-on sensing mechanism can exclude the possibility of framework collapse. However, small but appreciable changes in the relative intensity of the XRPD peaks were observed, so it seems that some changes in the crystal structure occurred. Indeed, X-ray photoelectron spectroscopy (XPS) analysis on $\mathbf{1}$ indicated the existence of $\mathrm{Cr}^{3+}$ cation in the framework of $\mathbf{1}$ after immersion as the observation of the $\mathrm{Cr} 2 \mathrm{p}_{3 / 2}$ and $\mathrm{Cr} 2 \mathrm{p}_{1 / 2}$ peaks at around 577.1 and $586.6 \mathrm{eV}$, respectively (Figure S8a). This might alter the intensity of the XRPD peaks. Notably, the O 1s peak in the XPS spectra did not shift after $\mathrm{Cr}^{3+}$ immersion (Figure S8b), and also the IR spectra did not change significantly (Figure S9). These phenomena imply that the influence of $\mathrm{Cr}^{3+}$ is not through bonding or there might be extremely weak interactions only between $\mathrm{Cr}^{3+}$ and the framework of $\mathbf{1}$ instead of the ligand-containing system [47]. Furthermore, the UV-vis absorption spectra of $\mathbf{1}$ were further checked, which demonstrated that $\mathbf{1}$ has an absorption band at around $350 \mathrm{~nm}$ corresponded to the excitation wavelength applied. Obviously, the absorbance increased remarkably after the addition of $\mathrm{Cr}^{3+}$ but exhibited no significant change after the addition of other different metal ions, such as $\mathrm{Al}^{3+}$ and $\mathrm{Fe}^{3+}$ (Figure S10), which implied that the turn-on effect of 1 toward $\mathrm{Cr}^{3+}$ can be properly explained by the absorbance caused enhancement (ACE) mechanism $[46,58]$. 
a

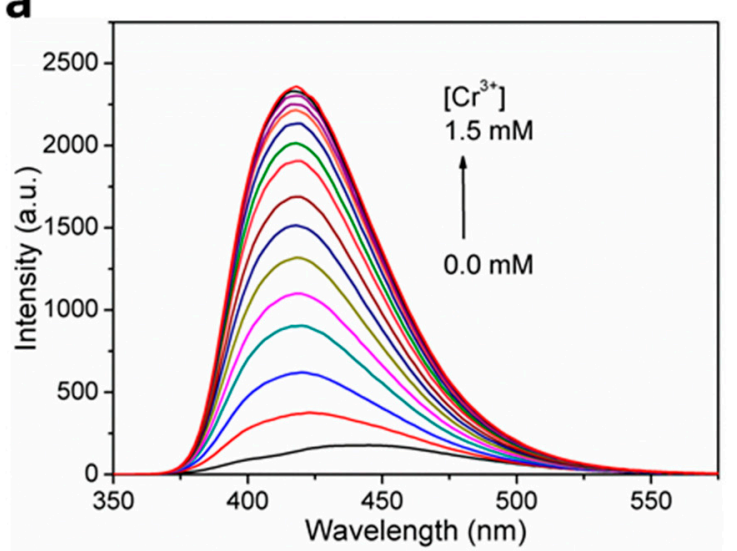

b

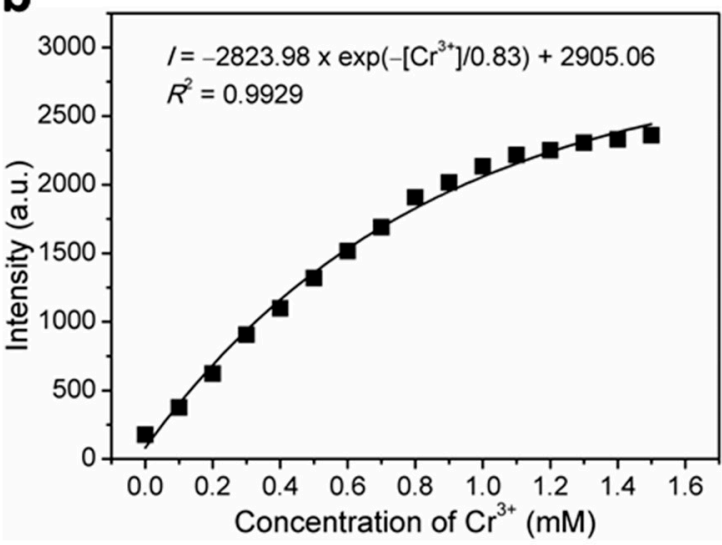

Figure 6. (a) Concentration-dependent fluorescence emission spectra of $\mathbf{1}$ in $\mathrm{H}_{2} \mathrm{O}$ suspensions upon incremental addition of $\mathrm{Cr}^{3+}$ ions when excited at $\lambda_{\mathrm{ex}}=306 \mathrm{~nm}$, and; (b) Plot of fluorescence intensity versus $\mathrm{Cr}^{3+}$ ion concentration for $\mathbf{1}$ in $\mathrm{H}_{2} \mathrm{O}$ suspensions.

\subsection{Fluorescence Sensing of Anions}

The fluorescence sensing properties of $\mathbf{1}$ toward anions were also explored, and ten different anions, including $\mathrm{F}^{-}, \mathrm{Cl}^{-}, \mathrm{Br}^{-}, \mathrm{I}^{-}, \mathrm{ClO}_{4}{ }^{-}, \mathrm{CO}_{3}{ }^{2-}, \mathrm{Cr}_{2} \mathrm{O}_{7}{ }^{2-}, \mathrm{CrO}_{4}{ }^{2-}, \mathrm{NO}_{3}{ }^{-}$, and $\mathrm{PO}_{4}{ }^{3-}$, were chosen. Similar to the procedures used for metal ion sensing, the fluorescence sensing measurements were carried out in water; each individual aqueous solution of anion was added to the well-prepared $\mathrm{H}_{2} \mathrm{O}$ suspension of $\mathbf{1}$, and the photoluminescence measurements were obtained at an excitation wavelength of $306 \mathrm{~nm}$ before and after addition of anion. As can be seen, most of the chosen anions exerted a relatively weak effect (intensity change $\leq 10 \%$ ) on the emission of $\mathbf{1}$ (Figure 7). The strongest fluorescence quenching effect was observed in the cases of the two chromium(VI) oxyanions, $\mathrm{Cr}_{2} \mathrm{O}_{7}{ }^{2-}$ and $\mathrm{CrO}_{4}{ }^{2-}$, which showed quenching efficiencies of about $90 \%$ and $74 \%$, respectively (quenching efficiency (\%) $=\left(I_{0}-I\right) / I_{0} \times 100 \%$, where $I_{0}$ and $I$ are the maximum fluorescence intensity of $\mathbf{1}$ before and after addition of analytes). Notably, when different concentrations of $\mathbf{1}$ in $\mathrm{H}_{2} \mathrm{O}$ suspensions were utilized, the high fluorescence quenching efficiencies are almost retained (Figure S5). Hence, the concentration of $\mathbf{1}$ in $\mathrm{H}_{2} \mathrm{O}$ suspension has no significant effect on the detection performances toward $\mathrm{Cr}_{2} \mathrm{O}_{7}{ }^{2-}$ and $\mathrm{CrO}_{4}{ }^{2-}$. Furthermore, interference experiments have shown that the quenching efficiencies of $\mathbf{1}$ toward $\mathrm{Cr}_{2} \mathrm{O}_{7}{ }^{2-}$ and $\mathrm{CrO}_{4}{ }^{2-}$ anions are hardly affected by other competitive anions (Figure 8), confirming the excellent anti-interference ability and thus the high selectivity of $\mathbf{1}$ as a fluorescence probe for detection of $\mathrm{Cr}_{2} \mathrm{O}_{7}{ }^{2-}$ and $\mathrm{CrO}_{4}{ }^{2-}$ anions in water.
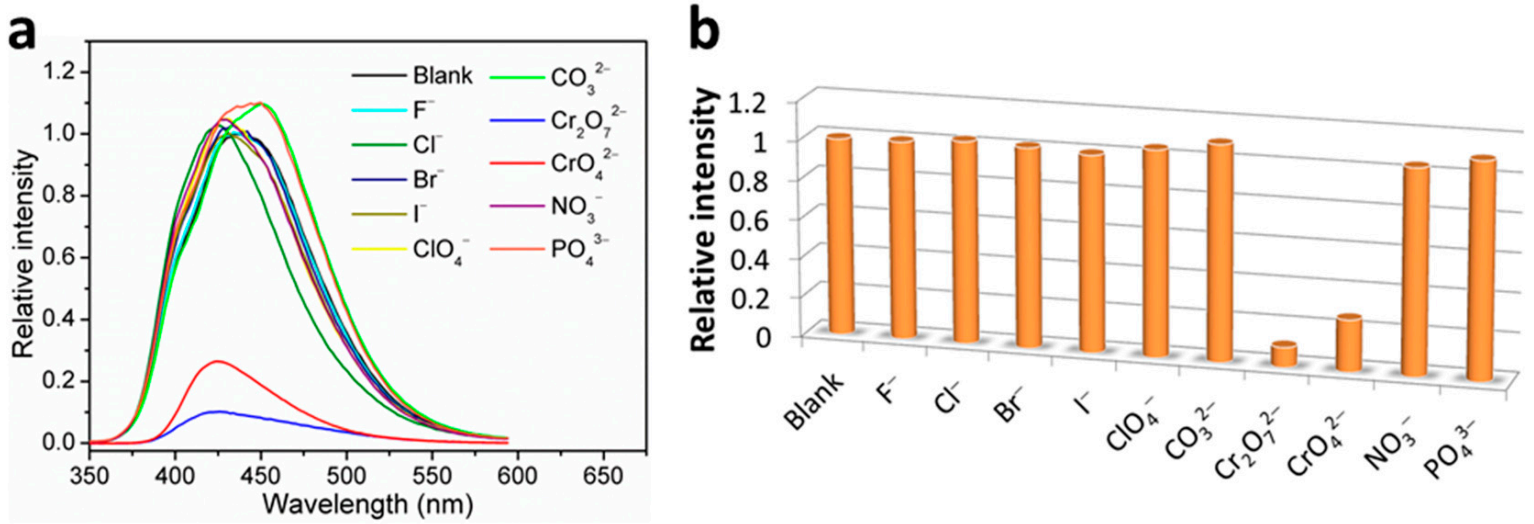

Figure 7. (a) Fluorescence emission spectra and (b) fluorescence relative ratio responses of $\mathbf{1}$ in $\mathrm{H}_{2} \mathrm{O}$ suspensions containing various anions at $1.0 \mathrm{mM}$. 


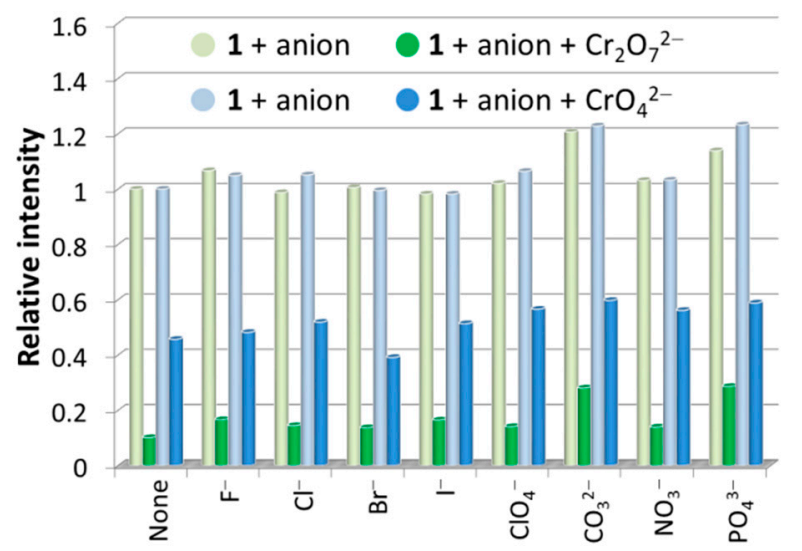

Figure 8. Fluorescence relative ratio responses of $\mathbf{1}$ in $\mathrm{H}_{2} \mathrm{O}$ suspensions containing various anions before and after addition of $\mathrm{Cr}_{2} \mathrm{O}_{7}{ }^{2-} / \mathrm{CrO}_{4}{ }^{2-}$ ions with equal concentrations at $1.0 \mathrm{mM}$.

Since $\mathrm{Cr}^{3+}$ enhances fluorescence of $\mathbf{1}$ in $\mathrm{H}_{2} \mathrm{O}$ suspension and $\mathrm{Cr}(\mathrm{VI})$ anions quench it, and both species can coexist in environmental conditions, it is of interest to study the influence of $\mathrm{Cr}^{3+}$ detection in the coexistence of $\mathrm{Cr}(\mathrm{VI})$ anions and vice versa. Experimental results clearly indicate that $\mathrm{Cr}(\mathrm{VI})$ anions strongly interfere with $\mathrm{Cr}^{3+}$ detection while $\mathrm{Cr}^{3+}$ ions cause no interference on the detection of $\mathrm{Cr}_{2} \mathrm{O}_{7}{ }^{2-}$ and $\mathrm{CrO}_{4}{ }^{2-}$ anions (Figure S11). Again, this confirms that 1 is highly selective for $\mathrm{Cr}_{2} \mathrm{O}_{7}{ }^{2-} / \mathrm{CrO}_{4}{ }^{2-}$ detection.

The detection sensitivity can be determined by quantitative analysis and LOD. Hence, fluorescent titration experiments were performed. As expected, the recorded fluorescence intensities gradually decreased with the gradual increase in the volume concentrations of $\mathrm{Cr}_{2} \mathrm{O}_{7}{ }^{2-}$ and $\mathrm{CrO}_{4}{ }^{2-}$ in the $\mathrm{H}_{2} \mathrm{O}$ suspensions of $\mathbf{1}$ (Figure 9a,b). Furthermore, the dependence of the fluorescence intensity on $\mathrm{Cr}_{2} \mathrm{O}_{7}{ }^{2-}$ or $\mathrm{CrO}_{4}{ }^{2-}$ ion concentration was investigated, which can be well fitted to $I=180.62 \times \exp \left(-\left[\mathrm{Cr}_{2} \mathrm{O}_{7}{ }^{2-}\right] / 0.56\right)-2.86\left(R^{2}\right.$ $=0.99717)$ for $\mathrm{Cr}_{2} \mathrm{O}_{7}{ }^{2-}$ and $\mathrm{I}=154.46 \times \exp \left(-\left[\mathrm{CrO}_{4}{ }^{2-}\right] / 1.06\right)+15.61\left(R^{2}=0.99789\right)$ for $\mathrm{Cr}_{2} \mathrm{O}_{7}{ }^{2-}$ (Figure S12). The quantification of fluorescence quenching effect was further examined through the Stern-Volmer equation. As observed, the Stern-Volmer plots for sensing $\mathrm{Cr}_{2} \mathrm{O}_{7}{ }^{2-}$ and $\mathrm{CrO}_{4}{ }^{2-}$ analytes by 1 both exhibited upward curves of $I_{0} / I$ against the analyte concentration over the titration concentrations (Figure 9c,d), implying the cooperation of dynamic and static quenching processes $[34,59,60]$. On the basis of quantitative titrations, the good linear regression analyses on Stern-Volmer plots gave the $K_{\mathrm{sv}}$ value of $2.52 \times 10^{3} \mathrm{M}^{-1}\left(R^{2}=0.99259\right)$ in the range of $0-0.5 \mathrm{mM}$ for sensing $\mathrm{Cr}_{2} \mathrm{O}_{7}{ }^{2-}$ and $1.42 \times 10^{3} \mathrm{M}^{-1}\left(R^{2}=0.99672\right)$ in the range of $0-2.0 \mathrm{mM}$ for sensing $\mathrm{CrO}_{4}{ }^{2-}$ (inset in Figure $9 \mathrm{c}, \mathrm{d}$ ). The LOD was determined to be $43.36 \mu \mathrm{M}$ (corresponding to $9.36 \mathrm{ppm}$ ) for $\mathrm{Cr}_{2} \mathrm{O}_{7}{ }^{2-}$ and $25.57 \mu \mathrm{M}$ (corresponding to $2.97 \mathrm{ppm}$ ) for $\mathrm{CrO}_{4}{ }^{2-}$ (Figure S13).

The plausible fluorescence-quenching mechanisms have been investigated. The XRPD patterns of 1 before and after treatment of $\mathrm{Cr}_{2} \mathrm{O}_{7}{ }^{2-}$ and $\mathrm{CrO}_{4}{ }^{2-}$ showed a high degree of similarity (Figure S7), suggesting the maintenance of framework integrity, thus ruling out framework collapse as being the fluorescence quenching mechanism. However, the excitation wavelength to irradiate 1 was greatly overlapped with the absorbance band of $\mathrm{Cr}_{2} \mathrm{O}_{7}{ }^{2-}$ and $\mathrm{CrO}_{4}{ }^{2-}$, implying that the competitive absorption of excitation energy might serve dominant influence on the fluorescence quenching detection of 1 toward $\mathrm{Cr}_{2} \mathrm{O}_{7}{ }^{2-}$ and $\mathrm{CrO}_{4}{ }^{2-}$. Further, energy transfer process might also contribute efforts in quenching the fluorescence of $\mathbf{1}$ because the fluorescence-emission band of $\mathbf{1}$ in $\mathrm{H}_{2} \mathrm{O}$ suspension was partially overlapped and the absorbance band of $\mathrm{Cr}_{2} \mathrm{O}_{7}{ }^{2-}$ and $\mathrm{CrO}_{4}{ }^{2-}$ in aqueous solutions (Figure S14). 

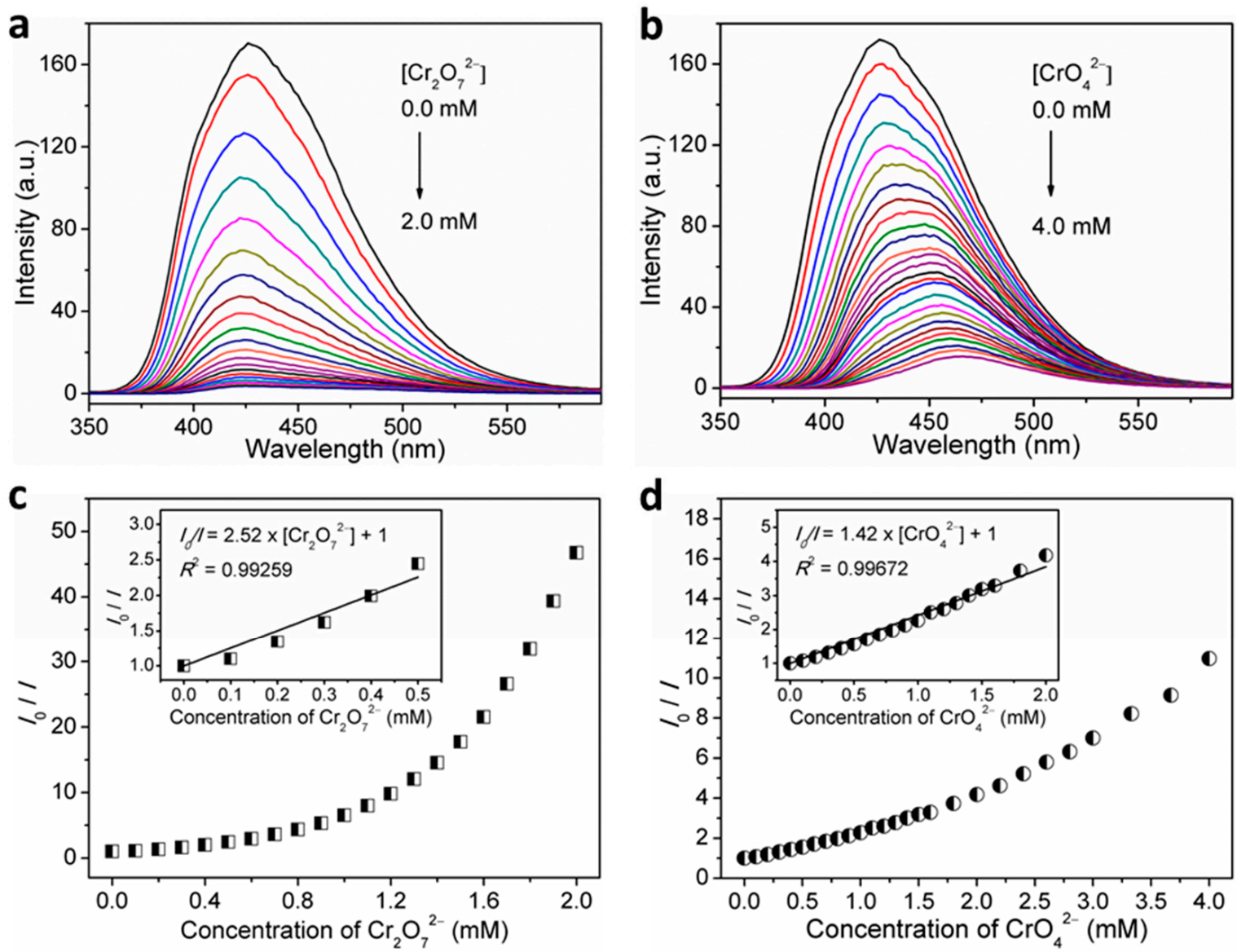

Figure 9. Concentration-dependent fluorescence spectra of $\mathbf{1}$ in $\mathrm{H}_{2} \mathrm{O}$ suspensions by incremental addition of (a) $\mathrm{Cr}_{2} \mathrm{O}_{7}{ }^{2-}$, and; (b) $\mathrm{CrO}_{4}{ }^{2-}$ upon excitation at $\lambda_{\mathrm{ex}}=306 \mathrm{~nm}$, and Stern-Volmer plot of $I_{0} / I$ versus concentration of; (c) $\mathrm{Cr}_{2} \mathrm{O}_{7}{ }^{2-}$, and; (d) $\mathrm{CrO}_{4}{ }^{2-}$ for $\mathbf{1}$ in $\mathrm{H}_{2} \mathrm{O}$ suspensions (inset: linear Stern-Volmer plot).

\section{Conclusions}

In this research, we have successfully synthesized a 2-fold interpenetrated coordination polymer 1 featuring a 4-connected cds network topology with the point symbol of $\left(6^{5} \cdot 8\right)$. Coordination polymer 1 emits fluorescence in both solid-state and suspension-phase of different solvents, making it a potential candidate to be employed in detection of $\mathrm{Cr}$ (III) cations via remarkable fluorescence enhancement response due to ACE mechanism, and in sensing of $\mathrm{Cr}(\mathrm{VI})$ oxyanions $\left(\mathrm{Cr}_{2} \mathrm{O}_{7}{ }^{2-}\right.$ and $\left.\mathrm{CrO}_{4}{ }^{2-}\right)$ via fluorescence-quenching effect due to collaboration of absorption competition and energy transfer process, with high sensitivity and selectivity.

Supplementary Materials: The following supporting information can be downloaded at: https: / / www.mdpi.com/article/10.3390/nano12010158/s1. Figure S1: Plot of the inter-net $\pi-\pi$ interactions between two neighboring naphthalimide skeletons in the two independent identical cds frameworks in the crystal structure of $\mathbf{1}$. Figure S2: TG curve of 1. Figure S3: Solid-state excitation (solid lines) and emission spectra (solid lines with symbols) of NI-mbpy-34, $\mathrm{Br}-1,3-\mathrm{H}_{2} \mathrm{bdc}$, and $\mathbf{1}$ at room temperature. Figure S4: Fluorescence emission spectra of $\mathbf{1}$ in $\mathrm{H}_{2} \mathrm{O}$ suspensions of different concentrations at room temperature upon excitation at $306 \mathrm{~nm}$. Inset: Fluorescence relative ratio responses of 1 in $\mathrm{H}_{2} \mathrm{O}$ suspensions of different concentrations. Figure S5: Effect of the concentration of 1 in $\mathrm{H}_{2} \mathrm{O}$ suspension on the fluorescence intensity responses upon addition of $\mathrm{Cr}^{3+}$ ions (enhancement) and $\mathrm{Cr}(\mathrm{VI})$ anions (quenching) at $1.0 \mathrm{mM}$. Figure S6: Linear region of fluorescence intensity for the $\mathrm{H}_{2} \mathrm{O}$ suspensions of complex 1 upon incremental addition of $\mathrm{Cr}^{3+}$ ions. The following table lists the relevant parameters of LOD for the $\mathrm{H}_{2} \mathrm{O}$ suspensions of complex 1 toward $\mathrm{Cr}^{3+}$ ions. Conditions: $\lambda_{e m}=414 \mathrm{~nm}\left(\lambda_{\mathrm{ex}}=280 \mathrm{~nm}\right)$. Figure S7: XRPD patterns of 1 before and 
after immersing in $\mathrm{Cr}^{3+}, \mathrm{Cr}_{2} \mathrm{O}_{7}{ }^{2-}$, and $\mathrm{CrO}_{4}{ }^{2-}$ aqueous solutions for 24 h. Figure S8: (a) XPS high resolution spectra of $\mathrm{Cr} 2 p$ for $\mathbf{1}$ after sensing $\mathrm{Cr}^{3+}$. (b) XPS high resolution spectra of $\mathrm{O} 1 \mathrm{~s}$ for $\mathbf{1}$ before and after sensing $\mathrm{Cr}^{3+}$. Figure S9: IR spectra of $\mathbf{1}$ before and after immersing in $\mathrm{Cr}^{3+}$ aqueous solution for $24 \mathrm{~h}$. Figure S10: UV-vis spectra of 1 before and after immersing in $\mathrm{Cr}^{3+}, \mathrm{Al}^{3+}, \mathrm{Fe}^{3+}$ aqueous solutions for $24 \mathrm{~h}$. Figure S11: Fluorescence emission spectra of 1 in $\mathrm{H}_{2} \mathrm{O}$ suspension $(1 \mathrm{mg} / 3 \mathrm{~mL})$ before and after addition of interfering/analyte ions at room temperature upon excitation at 306 nm. Figure S12: Fluorescence intensity traces $\left(\lambda_{\mathrm{em}}=438 \mathrm{~nm}\right)$ for the $\mathrm{H}_{2} \mathrm{O}$ suspensions of 1 upon incremental addition of $\mathrm{Cr}_{2} \mathrm{O}_{7}{ }^{2-}$ and $\mathrm{CrO}_{4}{ }^{2-}$ ions when excited at $306 \mathrm{~nm}$, following the first-order exponential decay. Figure S13: Linear region of fluorescence intensity $\left(\lambda_{\mathrm{em}}=438 \mathrm{~nm}\right)$ for the $\mathrm{H}_{2} \mathrm{O}$ suspensions of 1 upon incremental addition of $\mathrm{Cr}_{2} \mathrm{O}_{7}{ }^{2-}$ and $\mathrm{CrO}_{4}{ }^{2-}$ ions when excited at $306 \mathrm{~nm}$. The following table lists the relevant parameters of LOD for the $\mathrm{H}_{2} \mathrm{O}$ suspensions of 1 toward $\mathrm{Cr}_{2} \mathrm{O}_{7}{ }^{2-}$ and $\mathrm{CrO}_{4}{ }^{2-}$ ions. Figure S14: Spectral overlap between the normalized emission spectra of $\mathbf{1}$ in $\mathrm{H}_{2} \mathrm{O}$ suspensions and the normalized absorption spectra of $\mathrm{Cr}_{2} \mathrm{O}_{7}{ }^{2-}$ and $\mathrm{CrO}_{4}{ }^{2-}$ in aqueous solutions.

Author Contributions: J.-Y.W. conceived and designed the experiments; K.-S.L. and M.-J.T. performed the experiments; M.-J.T. and J.-Y.W. analyzed the data; J.-Y.W. contributed reagents/materials/ analysis tools; J.-Y.W. wrote the paper. All authors have read and agreed to the published version of the manuscript.

Funding: This research was financially supported the Ministry of Science and Technology of Taiwan (MOST 106-2113-M-260-007-, MOST 107-2113-M-260-001-, and MOST 108-2113-M-260-002-) and National Chi Nan University.

Data Availability Statement: All required data is provided within the manuscript.

Acknowledgments: The authors gratefully acknowledge the Advanced High-Tech Research Center of National Chi Nan University (MOST 110-2731-M-260-001-, NMR004800, MS004800, XRD003300, TA000400) and the Instrument Center of National Chung Hsing University (MOST 110-2731-M-005001-, XRD001300, EA000100, ESCA00003100) for providing valuable assistance on research support.

Conflicts of Interest: The authors declare no conflict of interest.

\section{References}

1. Ansari, S.; Masoum, S. Recent advances and future trends on molecularly imprinted polymer-based fluorescence sensors with luminescent carbon dots. Talanta 2021, 223, 121411. [CrossRef]

2. Sun, X.; Lei, Y. Fluorescent carbon dots and their sensing applications. Trends Analyt. Chem. 2017, 89, 163-180. [CrossRef]

3. Ebrahim, S.; Shokry, A.; Khalil, M.M.A.; Ibrahim, H.; Soliman, M. Polyaniline/Ag nanoparticles/graphene oxide nanocomposite fluorescent sensor for recognition of chromium (VI) ions. Sci. Rep. 2020, 10, 13617. [CrossRef]

4. Wang, M.; Guo, L.; Cao, D. Amino-Functionalized Luminescent Metal-Organic Framework Test Paper for Rapid and Selective Sensing of $\mathrm{SO}_{2}$ Gas and Its Derivatives by Luminescence Turn-On Effect. Anal. Chem. 2018, 90, 3608-3614. [CrossRef]

5. Tian, X.; Murfin, L.C.; Wu, L.; Lewis, S.E.; James, T.D. Fluorescent small organic probes for biosensing. Chem. Sci. 2021, 12, 3406-3426. [CrossRef] [PubMed]

6. Sunnapu, O.; Kotla, N.G.; Maddiboyina, B.; Asthana, G.S.; Shanmugapriya, J.; Sekar, K.; Singaravadivel, S.; Sivaraman, G. Rhodamine based effective chemosensor for Chromium(III) and their application in live cell imaging. Sens. Actuators B Chem. 2017, 246, 761-768. [CrossRef]

7. Su, Y.; Wang, Y.; Li, X.; Li, X.; Wang, R. Imidazolium-based porous organic polymers: Anion exchange-driven capture and luminescent probe of $\mathrm{Cr}_{2} \mathrm{O}_{7}{ }^{2-}$. ACS Appl. Mater. Interfaces 2016, 8, 18904-18911. [CrossRef] [PubMed]

8. Jin, M.; Mou, Z.-L.; Zhang, R.-L.; Liang, S.-S.; Zhang, Z.-Q. An efficient ratiometric fluorescence sensor based on metal-organic frameworks and quantum dots for highly selective detection of 6-mercaptopurine. Biosens. Bioelectron. 2017, 91, 162-168. [CrossRef] [PubMed]

9. Zhang, M.Y.; Huang, R.F.; Ma, X.G.; Guo, L.H.; Wang, Y.; Fan, Y.M. Selective fluorescence sensor based on ion-imprinted polymer-modified quantum dots for trace detection of $\mathrm{Cr}(\mathrm{VI})$ in aqueous solution. Anal. Bioanal. Chem. 2019, 411, 7165-7175. [CrossRef]

10. Chen, D.; Wu, G.H.; Wang, Z.Q.; Ren, W.Z.; Zhang, Y.J.; Wu, A.G. Selective colorimetric detection of Cr(III) and Cr(VI) using gallic acid capped gold nanoparticles. Dalton Trans. 2016, 45, 8347-8354.

11. Chen, X.; Xu, Y.; Li, H. Lanthanide organic/inorganic hybrid systems: Efficient sensors for fluorescence detection. Dyes Pigments 2020, 178, 108386. [CrossRef]

12. Liu, X.-Y.; Lustig, W.P.; Li, J. Functionalizing Luminescent Metal-Organic Frameworks for Enhanced Photoluminescence. ACS Energy Lett. 2020, 5, 2671-2680. [CrossRef] 
13. Zhang, Y.; Yuan, S.; Day, G.; Wang, X.; Yang, X.; Zhou, H.C. Luminescent sensors based on metal-organic frameworks. Coord. Chem. Rev. 2018, 354, 28-45. [CrossRef]

14. Karmakar, A.; Samanta, P.; Dutta, S.; Ghosh, S.K. Fluorescent “Turn-on" Sensing Based on Metal-Organic Frameworks (MOFs). Chem. Asian J. 2019, 14, 4506-4519. [CrossRef] [PubMed]

15. Lv, R.; Wang, J.; Zhang, Y.; Li, H.; Yang, L.; Liao, S.; Gu, W.; Liu, X. An amino-decorated dual-functional metal-organic framework for highly selective sensing of $\mathrm{Cr}(\mathrm{III})$ and $\mathrm{Cr}(\mathrm{VI})$ ions and detection of nitroaromatic explosives. J. Mater Chem. A 2016, 4, 15494-15500. [CrossRef]

16. Calevro, F.; Campani, S.; Ragghianti, M.; Bucci, S.; Mancino, G. Tests of toxicity and teratogenicity in biphasic vertebrates treated with heavy metals $\left(\mathrm{Cr}^{3+}, \mathrm{A}^{3+}, \mathrm{Cd}^{2+}\right)$. Chemosphere 1998, 37, 3011-3017. [CrossRef]

17. Coetzee, J.J.; Bansal, N.; Chirwa, E.M.N. Chromium in environment, its toxic effect from chromite-mining and ferrochrome industries, and its possible bioremediation. Expo. Health 2020, 12, 51-62. [CrossRef]

18. Dayan, A.; Paine, A. Mechanisms of chromium toxicity, carcinogenicity and allergenicity: Review of the literature from 1985 to 2000. Hum. Exp. Toxicol. 2001, 20, 439-451. [CrossRef]

19. Costa, M. Toxicity and carcinogenicity of $\mathrm{Cr}(\mathrm{VI})$ in animal models and humans. Crit. Rev. Toxicol. 1997, 27, 431-442. [CrossRef]

20. WHO/SDE/WSH/03.04/4; Chromium in Drinking-Water. Background Document for Preparation of WHO Guidelines for DrinkingWater Quality. WHO: Geneva, Switzerland, 2003.

21. Jia, X.-X.; Yao, R.-X.; Zhang, F.-Q.; Zhang, X.-M. A Fluorescent Anionic MOF with $\mathrm{Zn}_{4}(\operatorname{trz})_{2}$ Chain for Highly Selective Visual Sensing of Contaminants: Cr(III) Ion and TNP. Inorg. Chem. 2017, 56, 2690-2696. [CrossRef]

22. Guo, X.-Y.; Zhao, F.; Liu, J.-J.; Liu, Z.-L.; Wang, Y.-Q. An ultrastable zinc(II)-organic framework as a recyclable multi-responsive luminescent sensor for $\mathrm{Cr}(\mathrm{III}), \mathrm{Cr}(\mathrm{VI})$ and 4-nitrophenol in the aqueous phase with high selectivity and sensitivity. J. Mater. Chem. A 2017, 5, 20035-20043. [CrossRef]

23. Sun, Z.; Yang, M.; Ma, Y.; Li, L. Multi-Responsive Luminescent Sensors Based on Two-Dimensional Lanthanide-Metal Organic Frameworks for Highly Selective and Sensitive Detection of $\mathrm{Cr}(\mathrm{III})$ and $\mathrm{Cr}(\mathrm{VI})$ Ions and Benzaldehyde. Cryst. Growth Des. 2017, 17, 4326-4335. [CrossRef]

24. Dong, J.; Xu, H.; Hou, S.-L.; Wu, Z.-L.; Zhao, B. Metal-Organic Frameworks with $\mathrm{Tb}_{4}$ Clusters as Nodes: Luminescent Detection of Chromium(VI) and Chemical Fixation of $\mathrm{CO}_{2}$. Inorg. Chem. 2017, 56, 6244-6250. [CrossRef]

25. He, T.; Zhang, Y.-Z.; Kong, X.-J.; Yu, J.; Lv, X.-L.; Wu, Y.; Guo, Z.-J.; Li, J.-R. Zr(IV)-Based Metal-Organic Framework with T-Shaped Ligand: Unique Structure, High Stability, Selective Detection, and Rapid Adsorption of $\mathrm{Cr}_{2} \mathrm{O}_{7}{ }^{2-}$ in Water. ACS Appl. Mater. Interfaces 2018, 10, 16650-16659. [CrossRef] [PubMed]

26. Yu, H.; Fan, M.; Liu, Q.; Su, Z.; Li, X.; Pan, Q.; Hu, X. Two Highly Water-Stable Imidazole-Based Ln-MOFs for Sensing Fe ${ }^{3+}$, $\mathrm{Cr}_{2} \mathrm{O}_{7}{ }^{2-} / \mathrm{CrO}_{4}{ }^{2-}$ in a Water Environment. Inorg. Chem. 2020, 59, 2005-2010. [CrossRef] [PubMed]

27. Xu, S.; Shi, J.-J.; Ding, B.; Liu, Z.-Y.; Wang, X.-G.; Zhao, X.-J.; Yang, E.-C. A heterometallic sodium(I)-europium(III)-organic layer exhibiting dual-responsive luminescent sensing for nitrofuran antibiotics, $\mathrm{Cr}_{2} \mathrm{O}_{7}{ }^{2-}$ and $\mathrm{MnO}_{4}{ }^{-}$anions. Dalton Trans. 2019, 48, 1823-1834. [CrossRef] [PubMed]

28. Liu, W.; Wang, Y.; Bai, Z.; Li, Y.; Wang, Y.; Chen, L.; Xu, L.; Diwu, J.; Chai, Z.; Wang, S. A Hydrolytically Stable Luminescent Cationic Metal-organic Framework for Highly Sensitive and Selective Sensing of Chromate Anion in Natural Water Systems. ACS Appl. Mater. Interfaces 2017, 9, 16448-16457. [CrossRef] [PubMed]

29. Parmar, B.; Rachuri, Y.; Bisht, K.K.; Laiya, R.; Suresh, E. Conventional Synthesis of Zn(II)/Cd(II) Luminescent Coordination Polymers: Dual Sensing Probe for Selective Detection of Chromate Anions and TNP in Aqueous Phase. Inorg. Chem. 2017, 56, 2627-2638. [CrossRef] [PubMed]

30. Yao, Z.Q.; Li, G.Y.; Xu, J.; Hu, T.L.; Bu, X.H. A Water-Stable Luminescent Zn ${ }^{\mathrm{II}}$ Metal-Organic Framework as Chemosensor for High-Efficiency Detection of $\mathrm{Cr}^{\mathrm{VI}}$-Anions $\left(\mathrm{Cr}_{2} \mathrm{O}_{7}{ }^{2-}\right.$ and $\left.\mathrm{CrO}_{4}{ }^{2-}\right)$ in Aqueous Solution. Chem. Eur. J. 2018, 24, 3192-3198. [CrossRef]

31. Lv, R.; Li, H.; Su, J.; Fu, X.; Yang, B.; Gu, W.; Liu, X. Zinc Metal-Organic Framework for Selective Detection and Differentiation of $\mathrm{Fe}(\mathrm{III})$ and $\mathrm{Cr}(\mathrm{VI})$ Ions in Aqueous Solution. Inorg. Chem. 2017, 56, 12348-12356. [CrossRef]

32. Zhou, X.; Shi, Y.-X.; Cao, C.; Ni, C.-Y.; Ren, Z.-G.; Young, D.J.; Lang, J.-P. Nickel(II)-Based Two-Dimensional Coordination Polymer Displaying Superior Capabilities for Selective Sensing of Cr(VI) Ions in Water. Cryst. Growth Des. 2019, 19, 3518-3528. [CrossRef]

33. Wu, X.-X.; Fu, H.-R.; Han, M.-L.; Zhou, Z.; Ma, L.-F. Tetraphenylethylene Immobilized Metal-Organic Frameworks: Highly Sensitive Fluorescent Sensor for the Detection of $\mathrm{Cr}_{2} \mathrm{O}_{7}{ }^{2-}$ and Nitroaromatic Explosives. Cryst. Growth Des. 2017, 17, 6041-6048. [CrossRef]

34. Sun, X.; Yao, S.; Yu, C.; Li, G.; Liu, C.; Huo, Q.; Liu, Y. An ultrastable Zr-MOF for fast capture and highly luminescence detection of $\mathrm{Cr}_{2} \mathrm{O}_{7}{ }^{2-}$ simultaneously in an aqueous phase. J. Mater. Chem. A 2018, 6, 6363-6369. [CrossRef]

35. Xiao, Q.-Q.; Dong, G.-Y.; Li, Y.-H.; Cui, G.-H. Cobalt(II)-Based 3D Coordination Polymer with Unusual 4,4,4-Connected Topology as a Dual-Responsive Fluorescent Chemosensor for Acetylacetone and $\mathrm{Cr}_{2} \mathrm{O}_{7}{ }^{2-}$. Inorg. Chem. 2019, 58, 15696-15699. [CrossRef] [PubMed]

36. Xiao, Q.-Q.; Li, Y.-H.; Liu, D.; Cui, G.-H. A water-stable luminescent Co(II) coordination polymer as probe for efficient detection of $\mathrm{Cr}(\mathrm{VI})$-anions $\left(\mathrm{Cr}_{2} \mathrm{O}_{7}{ }^{2-}\right.$ and $\left.\mathrm{CrO}_{4}{ }^{2-}\right)$ in aqueous solution. Inorg. Chem. Commun. 2020, 111, 107665. [CrossRef] 
37. Wang, Y.-N.; Wang, S.-D.; Cao, K.-Z.; Zou, G.-D.; Wang, S.-Y. Novel Zn(II) coordination polymer based on a semi-rigid tricarboxylate acid ligand: Synthesis, structure, and fluorescence recognition of acetylacetone and chromium(VI) anions. J. Solid State Chem. 2020, 302, 122380. [CrossRef]

38. Wang, Y.-N.; Wang, S.-D.; Cao, K.-Z.; Zou, G.-D.; Liu, H.-Q. A new fluorescent Cu(I) coordination polymer for selective detection of oxo-anion chromium(VI) in water. Inorg. Chem. Commun. 2021, 132, 108844. [CrossRef]

39. Huang, Y.-W.; Chuang, P.-M.; Wu, J.-Y. Solvent-Induced Controllable Supramolecular Isomerism: Phase Transformation, $\mathrm{CO}_{2}$ Adsorption, and Fluorescence Sensing toward $\mathrm{CrO}_{4}{ }^{2-}, \mathrm{Cr}_{2} \mathrm{O}_{7}{ }^{2-}, \mathrm{MnO}_{4}{ }^{-}$and $\mathrm{Fe}^{3+}$. Inorg. Chem. 2020, 59, 9095-9107. [CrossRef]

40. Jiang, Q.-J.; Lin, J.-Y.; Hu, Z.-J.; Hsiao, V.K.S.; Chung, M.-Y.; Wu, J.-Y. Luminescent Zinc(II) Coordination Polymers of Bis(pyridin4-yl)benzothiadiazole and Aromatic Polycarboxylates for Highly Selective Detection of Fe(III) and High Valent Oxyanions. Cryst. Growth Des. 2021, 21, 2056-2067. [CrossRef]

41. Zhang, J.-R.; Lee, J.-J.; Su, C.-H.; Tsai, M.-J.; Li, C.-Y.; Wu, J.-Y. From lamellar net to bilayered-lamella and to porous pillaredbilayer: Reversible crystal-to-crystal transformation, $\mathrm{CO}_{2}$ adsorption, and fluorescence detection of $\mathrm{Fe}^{3+}, \mathrm{Al}^{3+}, \mathrm{Cr}^{3+}, \mathrm{MnO}_{4}{ }^{-}$, and $\mathrm{Cr}_{2} \mathrm{O}_{7}{ }^{2-}$ in water. Dalton Trans. 2020, 49, 14201-14215. [CrossRef]

42. Chuang, P.-M.; Wu, J.-Y. A highly stable $\mathrm{Zn}$ coordination polymer exhibiting $\mathrm{pH}$-dependent fluorescence and as a visually ratiometric and on-off fluorescence sensor. CrystEngComm 2021, 23, 5226-5240. [CrossRef]

43. Chuang, P.-M.; Huang, Y.-W.; Liu, Y.-L.; Wu, J.-Y. Influence of linker substitution on fluorescence responsive sensing of isostructural coordination polymers: Visual turn-on, ratiometric, and turn-off sensing in water. CrystEngComm 2021, 23, 2222-2234. [CrossRef]

44. Tsai, M.-J.; Liao, K.-S.; Hsu, L.-J.; Wu, J.-Y. A luminescent Cd(II) coordination polymer as a fluorescence-responsive sensor for enhancement sensing of $\mathrm{Cr}^{3+}$ and $\mathrm{Al}^{3+}$ ions and quenching detection of chromium(VI) oxyanions. J. Solid State Chem. 2021, 304, 122564. [CrossRef]

45. Liang, X.; Jia, Y.; Zhan, Z.; Hu, M. A highly selective multifunctional Zn-coordination polymer sensor for detection of $\mathrm{Cr}$ (III), Cr (VI) ion, and TNP molecule. Appl. Organomet. Chem. 2019, 33, e4988. [CrossRef]

46. Tian, X.-M.; Yao, S.-L.; Qiu, C.-Q.; Zheng, T.-F.; Chen, Y.-Q.; Huang, H.; Chen, J.-L.; Liu, S.-J.; Wen, H.-R. Turn-On Luminescent Sensor toward $\mathrm{Fe}^{3+}, \mathrm{Cr}^{3+}$, and $\mathrm{Al}^{3+}$ Based on a $\mathrm{Co}(\mathrm{II})$ Metal-Organic Framework with Open Functional Sites. Inorg. Chem. 2020, 59, 2803-2810. [CrossRef]

47. Yu, Y.; Wang, Y.; Yan, H.; Lu, J.; Liu, H.; Li, Y.; Wang, S.; Li, D.; Dou, J.; Yang, L.; et al. Multiresponsive Luminescent Sensitivities of a 3D Cd-CP with Visual Turn-on and Ratiometric Sensing toward $\mathrm{Al}^{3+}$ and $\mathrm{Cr}^{3+}$ as Well as Turn-off Sensing toward Fe ${ }^{3+}$. Inorg. Chem. 2020, 59, 3828-3837. [CrossRef]

48. Li, H.; Li, D.; Qin, B.; Li, W.; Zheng, H.; Zhang, X.; Zhang, J. Turn-on fluorescence in a stable Cd(II) metal-organic framework for highly sensitive detection of $\mathrm{Cr}^{3+}$ in water. Dyes Pigments 2020, 178, 108359. [CrossRef]

49. Tsai, M.-J.; Li, C.-Y.; Wu, J.-Y. Luminescent $\mathrm{Zn}$ (II) coordination polymers as efficiently fluorescent sensors for highly sensitive detection of explosive nitroaromatics. CrystEngComm 2018, 20, 6762-6774. [CrossRef]

50. Chen, T.-C.; Tsai, M.-J.; Wu, J.-Y. Fluorescent Cadmium Bipillared-Layer Open Frameworks: Synthesis, Structures, Sensing of Nitro Compounds, and Capture of Volatile Iodine. Chem. Eur. J. 2019, 25, 1337-1344. [CrossRef] [PubMed]

51. Tsai, M.-J.; Li, C.-Y.; Wu, J.-Y. A highly stable luminescent coordination polymer for sensing of volatile iodine and its metal-ion exchange properties with $\mathrm{Cu}^{2+}$ ions. J. Photochem. Photobiol. A Chem. 2020, 389, 112256. [CrossRef]

52. Su, C.-H.; Tsai, M.-J.; Wang, W.-K.; Li, Y.-Y.; Wu, J.-Y. Engineering Tailored Bifunctional Luminescent Pillared-Layer Frameworks for Adsorption of $\mathrm{CO}_{2}$ and Sensitive Detection of Nitrobenzene in Water Media. Chem. Eur. J. 2021, 27, 6529-6537. [CrossRef]

53. Sheldrick, G.M. A short history of SHELX. Acta Crystallogr. Sect. A 2008, 64, 112-122. [CrossRef] [PubMed]

54. Sheldrick, G.M. Crystal structure refinement with SHELXL. Acta Crystallogr. Sect. C 2015, 71, 3-8. [CrossRef]

55. Farrugia, L.J. WinGX and ORTEP for Windows: An update. J. Appl. Crystallogr. 2012, 45, 849-854. [CrossRef]

56. Wang, S.; Cao, T.; Yan, H.; Li, Y.; Lu, J.; Ma, R.; Li, D.; Dou, J.; Bai, J. Functionalization of Microporous Lanthanide-Based MetalOrganic Frameworks by Dicarboxylate Ligands with Methyl-Substituted Thieno[2,3-b]thiophene Groups: Sensing Activities and Magnetic Properties. Inorg. Chem. 2016, 55, 5139-5151. [CrossRef]

57. Song, J.-F.; Luo, J.-J.; Jia, Y.-Y.; Xin, L.-D.; Lin, Z.-Z.; Zhou, R.-S. Solvent-induced construction of two zinc supramolecular isomers: Synthesis, framework flexibility, sensing properties, and adsorption of dye molecules. RSC Adv. 2017, 7, 36575-36584. [CrossRef]

58. Wang, M.; Guo, L.; Cao, D.P. Metal-Organic Framework as Luminescence Turn-on Sensor for Selective Detection of Metal Ions: Absorbance Caused Enhancement Mechanism. Sens. Actuators B 2018, 256, 839-845. [CrossRef]

59. Sharma, V.; De, D.; Pal, S.; Saha, P.; Bharadwaj, P.K. A 2D Coordination Network That Detects Nitro Explosives in Water, Catalyzes Baylis-Hillman Reactions, and Undergoes Unusual 2D $\rightarrow$ 3D Single-Crystal to Single-Crystal Transformation. Inorg. Chem. 2017, 56, 8847-8855. [CrossRef] [PubMed]

60. Cao, L.H.; Shi, F.; Zhang, W.M.; Zang, S.Q.; Mak, T.C.W. Selective Sensing of $\mathrm{Fe}^{3+}$ and $\mathrm{Al}^{3+}$ Ions and Detection of 2,4,6Trinitrophenol by a Water-Stable Terbium-Based Metal-Organic Framework. Chem. Eur. J. 2015, 21, 15705-15712. [CrossRef] [PubMed] 